\title{
OPEN Oxidation state and metasomatism of the lithospheric mantle beneath the Rae Craton, Canada: strong gradients reflect craton formation and evolution
}

\author{
Alan B. Woodland ${ }^{1,2 \bowtie}$, Carolin Gräf ${ }^{1}$, Theresa Sandner ${ }^{1}$, Heidi E. Höfer ${ }^{1}$, \\ Hans-Michael Seitz ${ }^{1,2}$, D. Graham Pearson ${ }^{3}$ \& Bruce A. Kjarsgaard ${ }^{4}$
}

We present the first oxidation state measurements for the subcontinental lithospheric mantle (SCLM) beneath the Rae craton, northern Canada, one of the largest components of the Canadian shield. In combination with major and trace element compositions for garnet and clinopyroxene, we assess the relationship between oxidation state and metasomatic overprinting. The sample suite comprises peridotite xenoliths from the central part (Pelly Bay) and the craton margin (Somerset Island) providing insights into lateral and vertical variations in lithospheric character. Our suite contains spinel, garnet-spinel and garnet peridotites, with most samples originating from 100 to $140 \mathrm{~km}$ depth. Within this narrow depth range we observe strong chemical gradients, including variations in oxygen fugacity $\left(f \mathrm{O}_{2}\right)$ of over 4 log units. Both Pelly Bay and Somerset Island peridotites reveal a change in metasomatic type with depth. Observed geochemical systematics and textural evidence support the notion that Rae SCLM developed through amalgamation of different local domains, establishing chemical gradients from the start. These gradients were subsequently modified by migrating melts that drove further development of different types of metasomatic overprinting and variable oxidation at a range of length scales. This oxidation already apparent at $\sim 100 \mathrm{~km}$ depth could have locally destabilised any pre-existing diamond or graphite.

Cratons contain the oldest rocks on Earth, exceeding $2 \mathrm{Ga}$ in age, and have played an integral role in the development of the continental crust ${ }^{1,2}$. One factor allowing the long-term $(>1 \mathrm{Ga})$ preservation of such crustal rocks is the existence of a thick lithospheric root that may extend to $250 \mathrm{~km}$ depth or more and which is chemically and physically distinct from the surrounding asthenosphere ${ }^{3-6}$. As such, the formation and physico-chemical evolution of this thick SCLM is integral to our understanding of crust-mantle dynamics from the early Earth to the present.

The Rae craton is one of the large Meso-Neoarchean cratons that make up the Canadian Shield (Fig. 1). It comprises a number of component crustal blocks that were amalgamated in the Archean at ca. $2.7-2.6 \mathrm{Ga}^{6-9}$. Somerset Island is located in the northernmost part of the Queen Maud block and Pelly Bay is situated on the Committee block, in the north-central Rae (Fig. 1). The Rae craton is bounded to the west by the $1.97 \mathrm{Ga}$ Thelon-Taltson magmatic zone, which developed during collision with the Slave craton ${ }^{7,10}$. Likewise, the Hearne craton accreted onto the southern margin of the Rae at $1.92 \mathrm{Ga}$, as presently represented by the Snowbird tectonic zone $\mathrm{e}^{10-12}$.

Radiogenic isotope studies of peridotite xenoliths erupted by kimberlites on Somerset Island ${ }^{14-19}$ revealed that the cratonic lithosphere stabilised by at least $2.8 \mathrm{Ga}$. Rhenium depletion model ages yield a broad mode in their distribution from 3.0 to $2.25 \mathrm{Ga}$, with a mean of $2.3 \pm 0.3 \mathrm{Ga}$, with no discernable relationship between age and depth ${ }^{18}$. In contrast, depletion model ages for peridotite xenoliths from Pelly Bay produce three age groups: Archean 2.8-2.6 Ga, Paleoproterozoic 2.1-1.7 Ga and "Recent" < $1 \mathrm{Ga}^{9}$. The Paleoproterozoic peridotites tend

${ }^{1}$ Institut Für Geowissenschaften, Goethe-Universität Frankfurt, Altenhöferallee 1, 60438 Frankfurt am Main, Germany. ${ }^{2}$ Frankfurt Isotope and Element Research Center (FIERCE), Goethe-Universität Frankfurt, Frankfurt am Main, Germany. ${ }^{3}$ Department of Earth and Atmospheric Sciences, University of Alberta, 1-26 Earth Science Building, Edmonton, AB T6G 2E3, Canada. ${ }^{4}$ Geological Survey of Canada, 615 Booth Street, Ottawa, ON K1A 0E9, Canada. ${ }^{\square}$ email: woodland@em.uni-frankfurt.de 


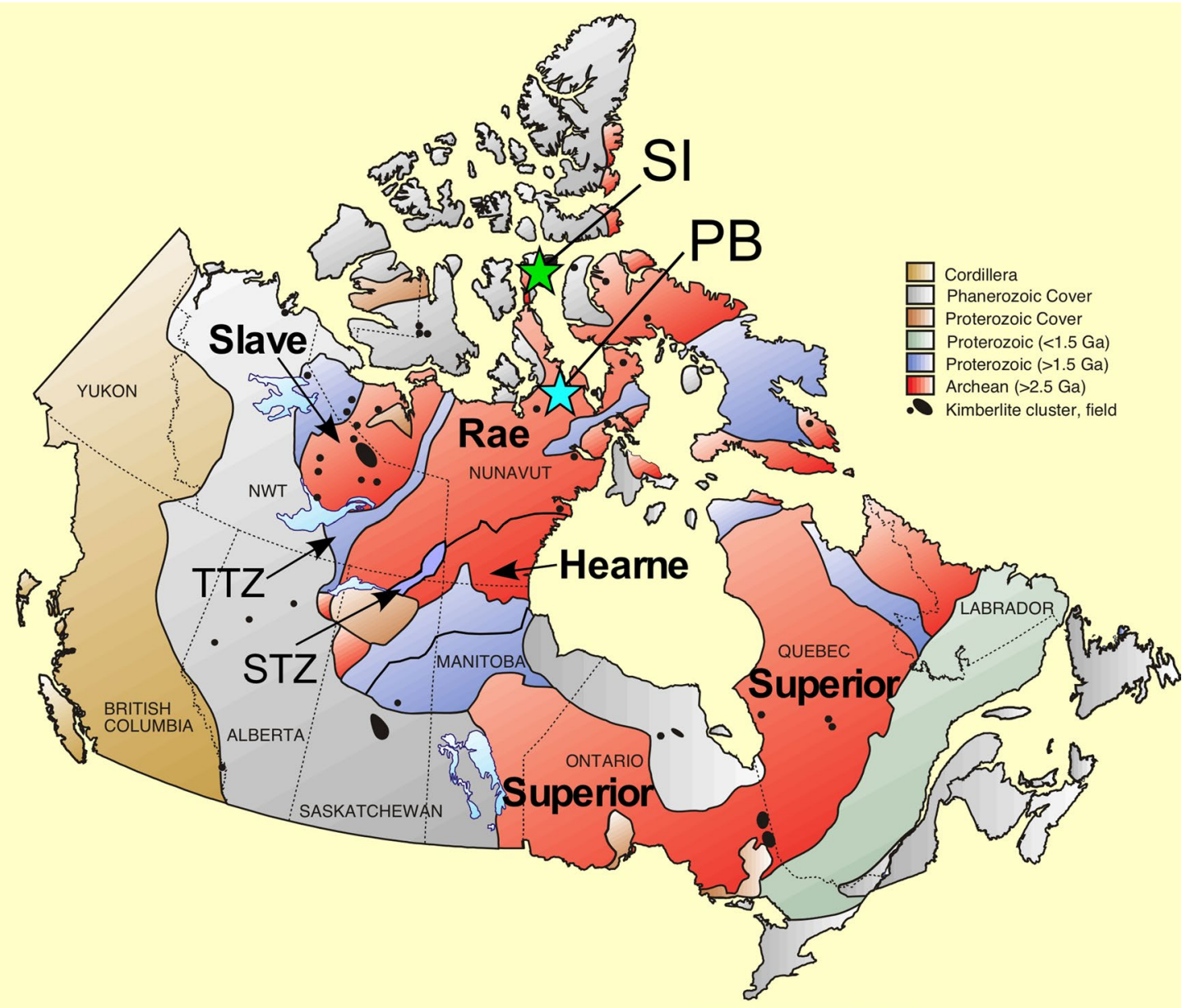

Figure 1. Schematic map of the Canadian shield illustrating the peridotite xenolith localities along with the constituent cratonic blocks and surrounding tectonic zones. SI Somerset Island, PB Pelly Bay, TTZ ThelonTaltson magmatic zone, STZ Snowbird tectonic zone (modified after Kjarsgaard ${ }^{13}$ ).

to occur at deeper levels, suggestive of a chronologically and structurally layered lithosphere, and are thought to represent more juvenile mantle, possibly related to metasomatic and/or magmatic interactions from regionalscale underplating during the Kivalliq-Nueltin event at $1.77-1.7 \mathrm{Ga}^{9}$.

Despite the large size of the Rae craton, much less is known about its mantle root than the neighboring small Slave craton, although recent geophysical studies have provided important information on its lithospheric structure ${ }^{6,8,20}$. However, no data are currently available on the oxidation state of the Rae SCLM. We have determined the oxidation state of two suites of peridotite xenoliths, one from the interior of the craton at Pelly Bay and one from the craton margin at Somerset Island. These results are then discussed within the context of differing metasomatic signatures recorded by garnet and clinopyroxene and depth of origin, as assessed by geothermobarometric calculations.

\section{Results}

Peridotite xenolith samples. A total of 30 peridotite xenoliths were investigated: 25 from four different kimberlite localities (Batty Bay, Nikos, JP north, JP south) on Somerset Island and five samples from Pelly Bay. Somerset Island peridotites were previously studied by Irvine et al.$^{18}$ and Bragagni et al. ${ }^{19}$ primarily for whole-rock Re-Os and PGE geochemistry and comprise five spinel peridotites, ten garnet peridotites and ten garnet-spinel peridotites. In the case of the garnet-spinel peridotites, the material available to us for five of the samples only contained spinel (i.e. no garnet). The Somerset Island kimberlites were emplaced 93-98 $\mathrm{Ma}$ ago $^{21}$. The smaller suite from Pelly Bay consists of one spinel lherzolite and two garnet-spinel lherzolites and two garnet lherzolites and is a subset of samples investigated by Liu et al. ${ }^{9}$ where they also focused on PGE geochemistry and Re-Os dating. Kimberlite emplacement at Pelly Bay has been dated at $546 \mathrm{Ma}^{22}$.

The Somerset Island samples mostly exhibit coarse equant or coarse tabular textures with only four samples (N1C, N2B, K11-A18, K13-A3) being porphyroclastic ${ }^{23}$, following the nomenclature of Harte ${ }^{24}$ (Supplementary Fig. S1). The stronger alteration of the Pelly Bay xenoliths precludes a textural assessment for several of the samples, but TU13-A2-3 and TU14-B2 are coarse tabular and porphyroclastic, respectively. Kelyphite alteration rims are variably developed around the garnets. Spinel is generally interstitial to olivine and ranges in color from brown to red-brown to dark brown, reflecting its $\mathrm{Cr} / \mathrm{Al}$ ratio (see below). In several cases, spinel occurs with a 

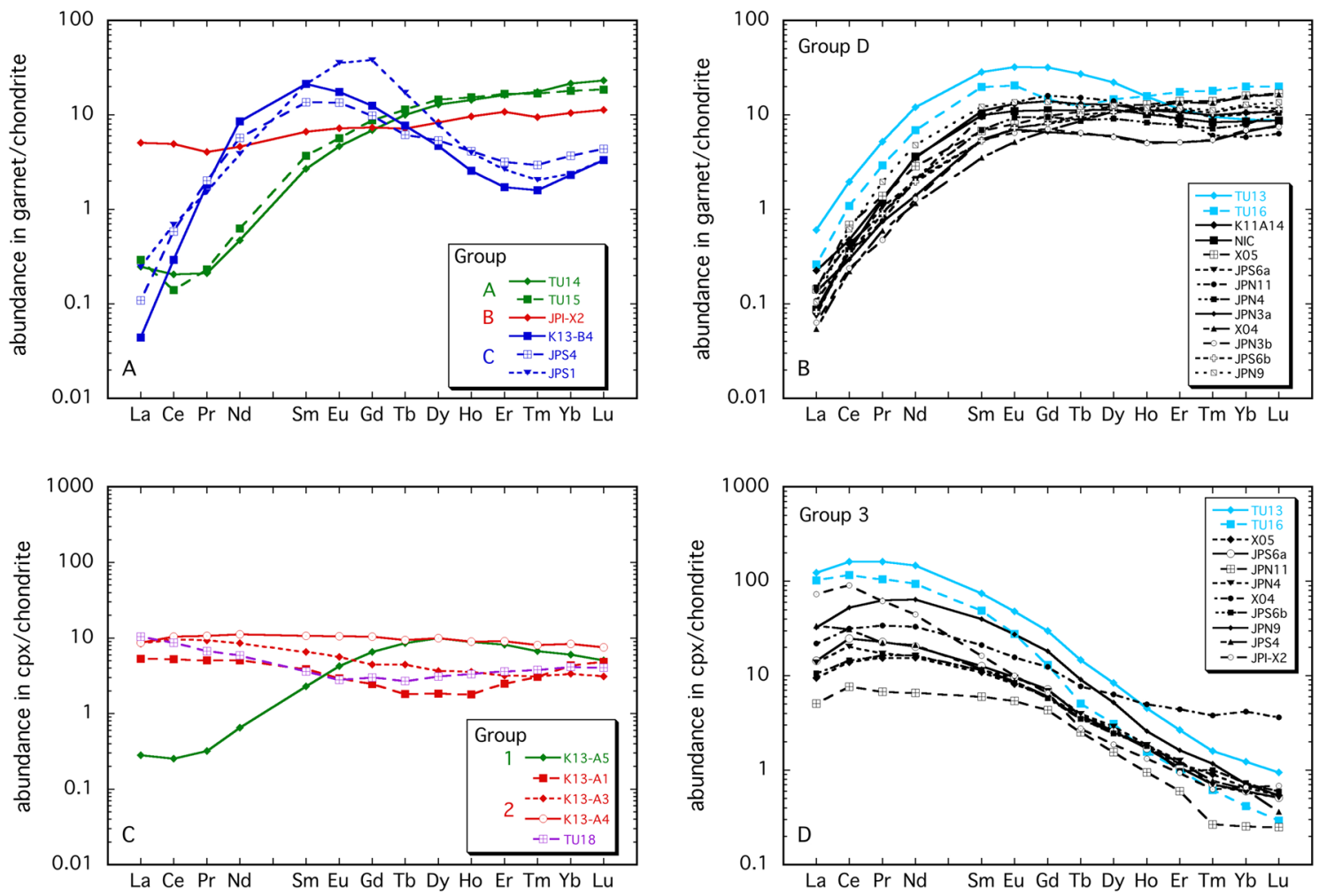

Figure 2. Chondrite-normalized REE patterns for garnet $(\mathbf{A}, \mathbf{B})$ and clinopyroxene $(\mathbf{C}, \mathbf{D})$ illustrating the different signatures as described in the text. Normalization is after McDonough and Sun ${ }^{27}$. The samples in blue in B-D are from Pelly Bay, the rest being from Somerset Island.

vermicular texture with clinopyroxene, orthopyroxene \pm olivine (Supplementary Fig. S1), suggesting that these intergrowths formed by the breakdown of garnet during upwelling ${ }^{25}$. In many garnet-spinel peridotites the two phases are not spatially associated with each other, suggesting that spinel and garnet may not necessarily be in mutual equilibrium (Supplementary Fig. S1).

Major element mineral chemistry. Major element compositions of analysed minerals are presented in Supplementary Tables 1, 2, 3, 4 and 5 . The $\mathrm{Fe}^{3+} / \Sigma \mathrm{Fe}$ of garnet, determined either by Mössbauer spectroscopy or the flank method (see "Methods"), is also reported in Supplementary Table 4 . The $\mathrm{Fe}^{3+} / \Sigma \mathrm{Fe}$ of spinel, determined either by Mössbauer spectroscopy or using secondary standards (see "Methods") is likewise listed in Supplementary Table 5. The minerals have compositions similar to those reported for upper-mantle xenoliths from other worldwide localities. Olivine $\mathrm{Mg} \#$ values $(\mathrm{Mg} \#=100 \times \mathrm{Mg} /(\mathrm{Mg}+\mathrm{Fe}))$ vary from 90.8 to 92.8 and $\mathrm{NiO}$ contents range from 0.31 to $0.43 \mathrm{wt} \%$, with most $>0.37 \mathrm{wt} \%$. Orthopyroxenes have $\mathrm{Mg \#}$ values ranging from 91.7 to 93.5 , $\mathrm{Al}_{2} \mathrm{O}_{3}$ contents of $0.88-3.2 \mathrm{wt} \%$ and $\mathrm{CaO}$ contents up to $0.87 \mathrm{wt} \%$ with an average of $0.57 \mathrm{wt} \%$. Where present, clinopyroxene is Al-rich Cr-diopside with higher $\mathrm{Mg} \#$ and $\mathrm{Al}_{2} \mathrm{O}_{3}$ contents in the spinel peridotites compared to those in the garnet-bearing samples (Fig. S2).

In a $\mathrm{Cr}_{2} \mathrm{O}_{3}-\mathrm{CaO}$ classification diagram all garnets plot within the G9, lherzolitic, field defined by Grütter

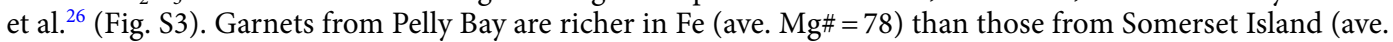
$\mathrm{Mg} \#=85$ ), but $\mathrm{Cr}$ contents overlap between the two suites (Supplementary Fig. S3). Fe ${ }^{3+} / \mathrm{SFe}$ ranges from 0.03 to 0.07 in the Pelly Bay garnets and from 0.03 to 0.14 in those from Somerset Island. Spinel compositions form two broad clusters in terms of their $\mathrm{Mg} \#$ and $\mathrm{Cr}$; one group having $\mathrm{Mg} \#<63$ and $\mathrm{Cr} \# \geq 70$ and the other group with Mg\# $\geq 65$ and Cr\#<42 (Supplementary Fig. S4). Except for one spinel harzburgite (JP3-X1), all other Crrich spinels are from garnet-spinel peridotites. Two other garnet-spinel peridotites contain spinels with relatively low $\mathrm{Cr}$ contents (K11-A18, K15-A4, Supplementary Fig. S4). Spinels have $\mathrm{Fe}^{3+} / \Sigma \mathrm{Fe}$ ranging from 0.01 to 0.26 (Supplementary Table 5).

Trace element mineral chemistry. Trace element abundances in garnet and clinopyroxene determined by LA-ICP-MS (see "Methods") are presented in Supplementary Table 6. The chondrite-normalised ${ }^{27}$ Rare Earth Element (REE) signatures of garnet permit the samples to be divided into four groups (Fig. 2A,B). Two samples from Pelly Bay (group A) exhibit a slight negative slope between $\mathrm{La}_{\mathrm{N}}$ and $\mathrm{Ce}_{\mathrm{N}}$, followed by steadily increasing normalised concentrations of light, middle and heavy Rare Earths ( $\mathrm{LREE}_{\mathrm{N}}, \mathrm{MREE}_{\mathrm{N}}$ and $\mathrm{HREE}_{\mathrm{N}}$, respectively). Although these patterns have the appearance of being geochemically "depleted", they have some of the highest concentrations of HREE and other elements like $\mathrm{Y}$ and Ga that are recognised as indicators of enrichment processes $^{28}$ (Fig. 2A, Supplementary Table 6). Garnet in one sample from Somerset Island has a flat normalised 
pattern (Group B, Fig. 2B). Group C samples have "sinusoidal" patterns with a peak occurring for the $\mathrm{MREE}_{\mathrm{N}}$ that systematically record the some of the lowest $\mathrm{Ti}, \mathrm{Yb}, \mathrm{Y}$ and $\mathrm{Ga}$ abundances in the sample set, reflecting a relatively depleted character ${ }^{28}$ (Fig. 2A, Supplementary Table 6), though the elevation of La and Ce over the MREE indicates some degree of enrichment. The majority of the xenoliths contain garnet exhibiting "normal" patterns ${ }^{29}$ with normalised abundances rising steeply from $\mathrm{La}_{\mathrm{N}}$ and then either remaining flat or having a slight sinusoidal character from $\mathrm{Sm}_{\mathrm{N}}$ to $\mathrm{Lu}_{\mathrm{N}}$ (Fig. 2B). These are designated as group D, with two samples from Pelly Bay having the highest $\mathrm{MREE}_{\mathrm{N}}$ and $\mathrm{LREE}_{\mathrm{N}}$ concentrations.

Trace element signatures of clinopyroxene can be divided into three groups. One spinel peridotite has a pattern with depleted $\mathrm{LREE}_{\mathrm{N}}$ and a hump-shaped form across the $\mathrm{MREE}_{\mathrm{N}}$ and $\mathrm{HREE}_{\mathrm{N}}$ with a maximum at $\mathrm{Dy}_{\mathrm{N}}$ (Fig. 2C). Clinopyroxenes in four other spinel peridotites have fairly flat $\mathrm{REE}_{\mathrm{N}}$ patterns, with slightly elevated LREE $_{\mathrm{N}}$ abundances (Fig. $2 \mathrm{C}$ ). Yb concentrations are also quite high in these samples $(>0.5 \mu \mathrm{g} / \mathrm{g}$, Supplementary Table 6). The remaining samples that contained analysable clinopyroxene exhibit enriched patterns with abundances steadily decreasing from $\mathrm{Ce}_{\mathrm{N}}$ to $\mathrm{Lu}_{\mathrm{N}}$ with a general flattening off between $\mathrm{La}_{\mathrm{N}}$ and $\mathrm{Nd}_{\mathrm{N}}$ (Fig. 2D). These samples are all garnet-bearing and in most cases, the coexisting garnet has a "normal" REE, i.e. group D pattern (two exceptions are JP1-X2 and JPS4, where the garnet has a flat or sinusoidal normalised REE signature, respectively).

Thermobarometry. The Somerset Island samples record equilibration temperatures from 830 to $1150{ }^{\circ} \mathrm{C}$ and pressures of 3.1-4.6 GPa, while the limited number of peritotites from Pelly Bay yield temperatures of 674$905^{\circ} \mathrm{C}$ with pressures ranging from 2.5 to $4.0 \mathrm{GPa}$ (see "Methods" and Supplementary Table 7). This corresponds to a depth range of approximately $100-150 \mathrm{~km}$ at Somerset Island and from $\sim 80$ to $130 \mathrm{~km}$ depth for the Pelly Bay suite. Thus our samples cover a depth range of $\sim 50 \mathrm{~km}$ through the lithospheric mantle at both localities.

Oxygen fugacity measurements. The $f \mathrm{O}_{2}$ values for garnet-bearing peridotites were calculated after Stagno et al. ${ }^{30}$ and for spinel-bearing peridotites after the Nell-Wood model ${ }^{31}$ (see "Methods"). Garnetbearing peridotite xenoliths from Pelly Bay have $\Delta \log f \mathrm{O}_{2}$ values between FMQ - 1.99 and FMQ - 1.35 (Supplementary Table 7). The only garnet-free xenolith from this suite (TU18) has a very low oxidation state of $\Delta \log f \mathrm{O}_{2}=\mathrm{FMQ}-4.13$. The peridotites from Somerset Island record $\Delta \log f \mathrm{O}_{2}$ values between FMQ -3.61 and $\mathrm{FMQ}+1.08$. For three garnet-spinel peridotites from Somerset Island and two from Pelly Bay, $\Delta \log f \mathrm{O}_{2}$ values could be estimated on the basis of $\mathrm{Fe}^{3+}$ contents in both garnet and spinel. In one case (NIC), values overlap within error and in the other cases (JPS, JPN9, TU13, TU16) the spinel-based equilibrium yielded values significantly more oxidised, underlining the fact that spinel and garnet may not always be in equilibrium with eachother (Supplementary Table 7). In fact these two phases are not generally observed to be in physical contact in our samples (e.g. Supplementary Fig. S1) and this behavior suggests that garnet $\mathrm{Fe}^{3+} / \Sigma \mathrm{Fe}$ may be sluggish to reset to changing redox conditions. This would be consistent with the fact that $\mathrm{Fe}^{3+}$ and $\mathrm{Fe}^{2+}$ reside on different crystallographic sites in garnet so that a change in $\mathrm{Fe}^{3+}$ content requires cation exchange (by diffusion or recrystallisation) rather than just the migration of an electron. Additionally, it could be related to the complex process of redistributing ferric iron between phases at the garnet-spinel transition since this also involves changes in the compositions and modes of orthopyroxene and clinopyroxene, along with the exchange of $\mathrm{Fe}^{3+}$ between garnet and spinel.

\section{Discussion}

The different REE signatures of garnet and clinopyroxene are process related; metasomatic interactions within the SCLM beneath the Rae craton can be further characterised and discriminated by considering further minor and trace element variations. The $\mathrm{Zr}-\mathrm{Y}$ systematics of garnet (Fig. 3A) reveal that the three Somerset Island samples with sinusoidal REE patterns (group C) plot within the fluid-metasomatism field of Griffin et al. ${ }^{32}$ and their low $\mathrm{Ti} / \mathrm{Eu}$ and variable $\mathrm{Zr} / \mathrm{Hf}$ point to a carbonatitic metasomatic agent ${ }^{33}$ (Fig. 3B). Many of the group D garnets plot within the melt metasomatism field of Griffin et al. ${ }^{32}$ and are distributed across the fields of carbonatitic and kimberlitic metasomatism in terms of their Ti/Eu and $\mathrm{Zr} / \mathrm{Hf}$ ratios (Fig. 3A,B). The group A and D garnets from Pelly Bay all have elevated Y contents and their Ti/Eu-Zr/Hf systematics place three of them in the field of carbonatitic metasomatism, with one group A sample (TU15) being significantly richer in Ti, suggesting interaction with a kimberlitic melt. Several samples from Somerset Island also exhibit similar Y enrichment with relatively no concomitant $\mathrm{Zr}$ enrichment (Fig. 3A), reminiscent of MARID-style metasomatism ${ }^{34}$. Thus, the portion of the Rae SCLM lying at 100-150 km records highly variable metasomatic interactions with at least three types of agent, carbonatitic, MARID and mafic silicate or kimberlitic melts; the geochemical signature of the mafic silicate melt being different between the craton margin at Somerset Island and mid-craton at Pelly Bay. Overall, the extent of Y- (and Ga) enrichment is similar to that observed for garnets from the deeper portions of the central Slave craton, the difference being that enrichment of the Rae SCLM occurs at significantly shallower depths ( $50 \mathrm{~km}$ shallower; Supplementary Fig. S5). Our observed range in Ti/Eu for garnet is much less than reported for the Slave SCLM, all giving values $<6000$ (Fig. 3B).

The trace element contents of clinopyroxene are consistent with this picture of several different types of metasomatic agents having interacted to different degrees with the peridotites. Diopside from the spinel peridotites in our suite generally exhibit the least extent of enrichment, as suggested by very low $\mathrm{Nd} / \mathrm{Yb}$ and $(\mathrm{La} / \mathrm{Yb})_{\mathrm{N}}$ ratios (Fig. 3C,D). However, sample K13-A5 stands out in terms of its extremely high Ti/Eu (Supplementary Table 6), reflecting a different type of metasomatism that caused Ti enrichment that also led to rutile formation. In contrast, clinopyroxene in four other spinel peridotites, including the shallowest-lying sample, TU18, has a $\mathrm{Ti} / \mathrm{Eu}$ ratio distinctly lower than that expected for a primitive mantle assemblage $(\mathrm{Ti} / \mathrm{Eu}=4742$, Uenver-Thiele et al. $\left.^{36}\right)$, implying some degree of interaction with mafic silicate melts. Of the garnet-bearing samples, four have 

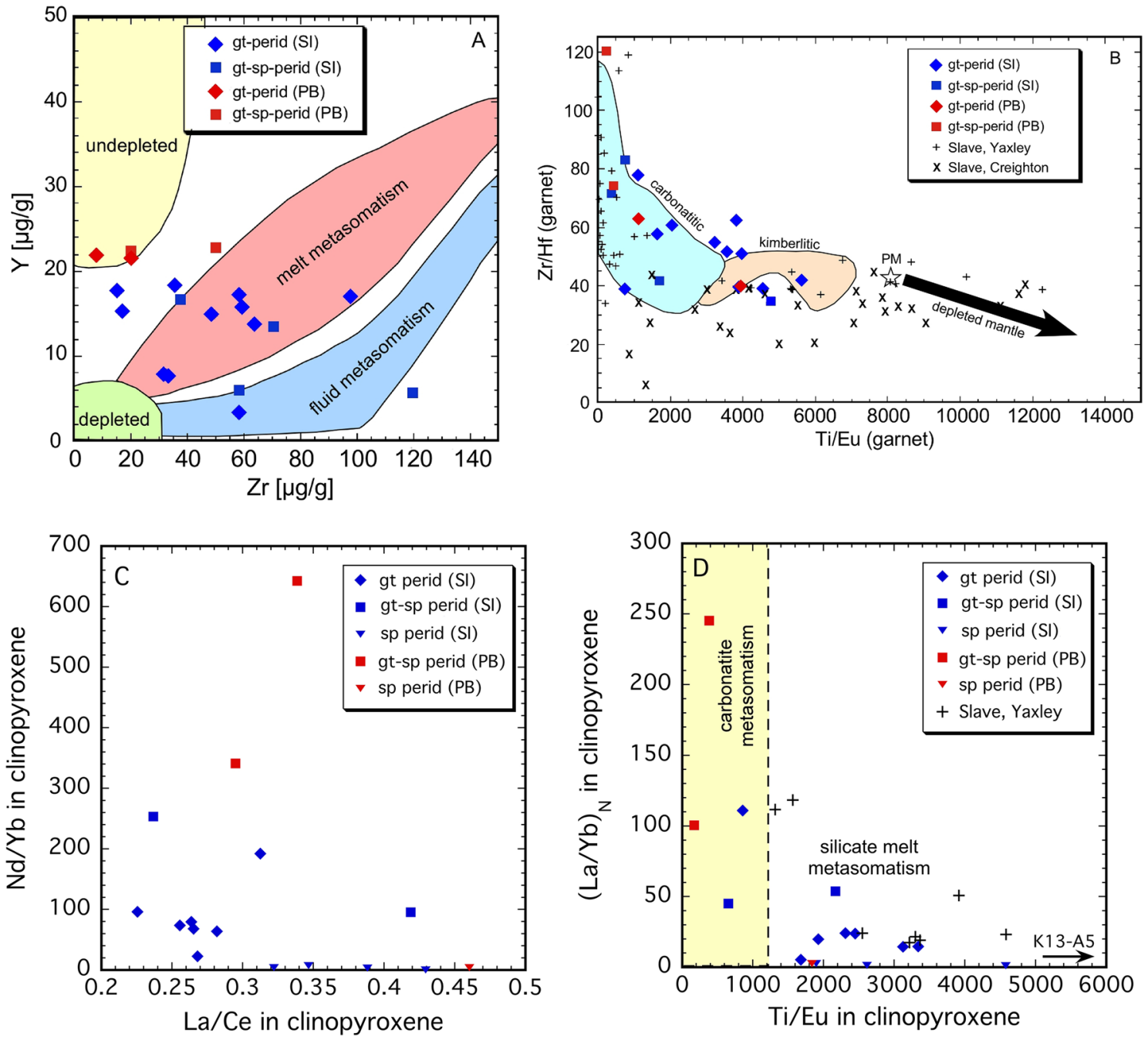

Figure 3. Selected trace element variations in garnet $(\mathbf{A}, \mathbf{B})$ and clinopyroxene $(\mathbf{C}, \mathbf{D})$ that can be used as indicators of metasomatic processes. Fields in $(\mathbf{A}, \mathbf{B})$ after Griffin et al. ${ }^{32}$ and Shu and Brey ${ }^{33}$, respectively. The demarcation of carbonatite and silicate melt metasomatism in $(\mathbf{D})$ is from Coltorti et al. ${ }^{35}$.

clinopyroxene with $\mathrm{Ti} / \mathrm{Eu}<1200$, which is indicative of carbonatitic metasomatism ${ }^{35}$ (Fig. 3D). Garnet compositions from these samples are consistent with this interpretation, including two samples from Pelly Bay (compare Fig. 3B,D). In fact, comparison of calculated partition coefficients between garnet and clinopyroxene (D $\left.{ }^{\mathrm{gt} / \mathrm{cpx}}\right)$ are indicative of trace element equilibrium as defined by Zack et al. ${ }^{37}$ in the samples where both phases could be analysed (see "Supplementary Information S1", Supplementary Fig. S6).

Variations in oxidation state range up to $\sim 4 \log$ units in our suites from Pelly Bay and Somerset Island (Fig. 4, Supplementary Table 7). This provides evidence for strong redox gradients present at mid-lithosphere depths. Along with the shallowest sample, a spinel peridotite from Pelly Bay (TU18), several deeper-lying spinelbearing peridotites from Somerset Island also record low $\Delta \log f \mathrm{O}_{2}$ values of $\leq \mathrm{FMQ}-3$, even when considered relative to the predicted depth- $f \mathrm{O}_{2}$ curve of Luth and Stachel ${ }^{38}$ for a primitive mantle bulk composition with $\mathrm{Fe}^{3+} / \Sigma \mathrm{Fe}=0.02^{39}$ that we take to represent pre-metasomatic cratonic lithosphere (Fig. 4 ). However, the relatively low $\mathrm{Ti} / \mathrm{Eu}$ and flat $\mathrm{REE}$ signatures of clinopyroxene in these samples attest to a certain degree of metasomatism that was apparently not significantly oxidising since the oxidation state of spinel peridotites can otherwise be readily reset by minor interactions ${ }^{40}$. Most garnet-bearing peridotites record higher $\Delta \log f \mathrm{O}_{2}$ values compared to the estimated primitive mantle systematics of Luth and Stachel ${ }^{38}$, consistent with them having experienced a variety of metasomatic interactions, as described previously (Fig. 4). The $\Delta \log f \mathrm{O}_{2}$ values derived from $\mathrm{Fe}^{3+} / \Sigma \mathrm{Fe}$ in spinel in some garnet-spinel peridotites are always higher than values determined from corresponding garnet $\mathrm{Fe}^{3+}$ contents, implying a late oxidative event during which the garnet composition was only partially reset. It is noteworthy that such oxidising conditions will also destabilise any pre-existing graphite or diamond (Fig. 4).

The range on oxidation state we observe for Rae SCLM is significantly greater than that reported for the mantle section beneath Udachnaya ${ }^{44}$ and is comparable with similarly metasomatised peridotite xenoliths from Kimberley ${ }^{45}$. The relatively oxidised domains occur at significantly shallower depths beneath the Rae craton compared to that observed for the Slave SCLM ${ }^{41,42}$ (Fig. 4). This mirrors the aforementioned enrichment of 


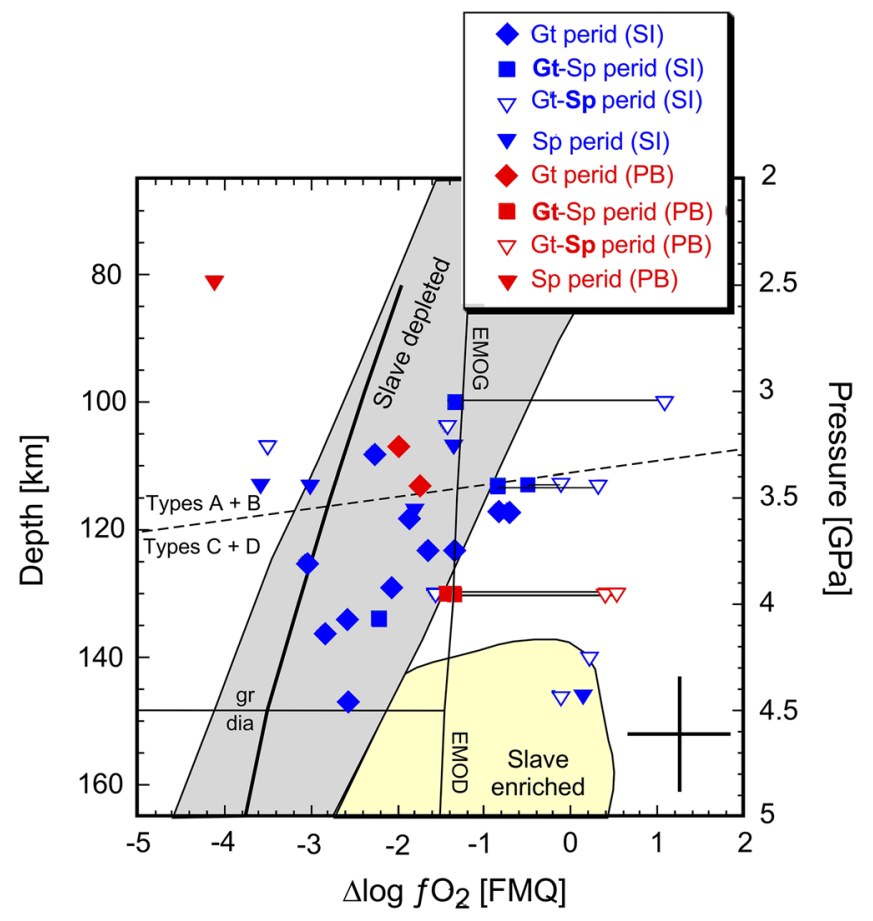

Figure 4. Variation in $\Delta \log f \mathrm{O}_{2}$ as a function of pressure/depth for samples from this study. Pressure was converted to depth assuming Depth $(\mathrm{km})=\mathrm{P}(\mathrm{GPa})^{\star} 32.4$. Thin horizontal lines connect $f \mathrm{O}_{2}$ values determined from garnet (solid) and spinel (open) equilibria from the same garnet-spinel peridotite xenolith. The dashed line demarcates the occurrences of type $\mathrm{A}$ and $\mathrm{B}$ garnets with respect to those with type $\mathrm{C}$ and $\mathrm{D}$ signatures. The grey and yellow fields encompass the depleted and enriched samples reported for the Slave craton (Yaxley et al. ${ }^{41}$; Creighton et al. ${ }^{42}$ ). The thick solid line illustrates the predicted variation for pre-metasomatic (primitive) mantle peridotite along a $40 \mathrm{~mW} / \mathrm{m}^{2}$ geotherm from Luth and Stachel ${ }^{38}$. The position of the graphite-diamond (gr-dia) transition was adopted from Kennedy and Kennedy ${ }^{43}$. EMOG and EMOD represent the positions of equilibria controlling carbonate stability in harzburgitic bulk compositions: enstatite + magnesite $=$ forsterite + graphite $(G)$ or diamond (D) $+\mathrm{O}_{2}$ from Luth and Stachel ${ }^{38}$, computed for a $40 \mathrm{~mW} / \mathrm{m}^{2}$ geotherm. The black cross in the lower right hand corner illustrates the estimated uncertainties in the $f \mathrm{O}_{2}$ and pressure calculations.

certain metasomatic indicator elements like Y and Ga also at shallower depths than reported for the Slave SCLM (Supplementary Fig. S5).

An important observation is that our peridotite suites comprise different mineralogies (spinel, garnet-spinel and garnet peridotites) in spite of the fact that the thermobarometric calculations reveal that virtually all samples originated from a fairly narrow depth range of 100-150 km (Supplementary Table 7). The observed variations in the $\mathrm{Yb}$ content of garnet (Supplementary Table 6) point to different mantle domains having experienced differing degrees of depletion by partial melting prior to being juxtaposed within the cratonic root (e.g. Creighton et $\mathrm{al}^{42}$ ). In addition, the relatively high $\mathrm{Cr} \#$ of some garnets $(>0.2)$ suggests an earlier history of partial melting at shallower depths, within the spinel stability field ${ }^{46,47}$. On the other hand, the occurrence of vermicular spinel in some samples, particularly sample TU18, suggest vertical movements from the garnet into the spinel stability field have also taken place. The physical separation of garnet and spinel in the garnet-spinel peridotites also implies multiple stages of mineral formation during and after consolidation of the lithospheric root beneath the Rae craton. On a regional scale, the SCLM beneath Pelly Bay is noticeably richer in FeO compared to the craton margin at Somerset Island (Supplementary Tables 2, 3 and 4) and differences in trace element signatures are also apparent between the two localities (Figs. 2A-D, 3 and Supplementary Fig. S5). These observations appear to be consistent with the numerical models of Wang et al. ${ }^{48}$ that envision a two-stage process of craton development with initial tectonic shortening followed by a subsequent phase of gravitational self-thickening. Oscillatory instabilities within the root can develop due to relative buoyancy, but can be attenuated by secular cooling that promotes stabilisation of the thickened lithosphere. Such a model would involve significant lateral and vertical movement, helping to explain the juxtaposition of different mantle domains at similar depths. This also implies that redox gradients at different scales will be the rule rather than the exception in cratonic mantle, promoting the possibility of redox melting as a process for generating small volume melts (e.g. Foley ${ }^{49}$ ).

The metasomatic signature is observed to change as a function of depth, with garnet groups A and B lying at shallow levels above $\sim 115 \mathrm{~km}$ and the more strongly enriched garnets belonging to groups $\mathrm{C}$ and $\mathrm{D}$ are found deeper (Fig. 4). An exception is one garnet-spinel peridotite (JPN9) that came from a depth of $100 \mathrm{~km}$ and is one of the most enriched samples of our suite (Fig. 2B,D). This distribution points to at least some metasomatic interactions having occurred since amalgamation of the cratonic root, with the agents rising from the asthenosphere. 
The picture is similar to that portrayed by Snyder et al. ${ }^{6,20}$ in their interpretive cross-section through the Rae craton, based in part on conductivity data. In this scheme, the SCLM peridotite domain represented by JPN9 would represent a finger of metasomatising melt that penetrated to shallower depths and caused partial oxidation (> FMQ) as recorded by the spinel. This contrasts with several spinel peridotites that originated from similar depths, but did not experience any oxidation. Thus the observed variations in mineralogy, metasomatic signatures and oxidation state of the SCLM at 100-150 km provide clues to the formation and evolution of the Rae craton in which tectonic juxtaposition of discrete mantle domains are an important feature of the construction of cratons. Not only does the assembly of the cratonic root produce geochemical gradients, but subsequent migration of melts through the consolidated lithospheric mantle cause additional heterogeneities to develop at different length scales, including locally modifying the oxidation state and influencing diamond stability.

\section{Methods}

Electronprobe microanalysis. Major and minor element analyses of minerals were determined with a JEOL JXA-8900 superprobe at Goethe Universität Frankfurt am Main. Measurements were made in wavelength dispersive mode with an acceleration potential of $15 \mathrm{kV}$, a beam current of $20 \mathrm{nA}$, a spot diameter of $3 \mu \mathrm{m}$ and employing a mix of natural and synthetic standards for calibration. Depending on the analysed element, counting times on the peak were $15-40 \mathrm{~s}$ and $20-40 \mathrm{~s}$ on the background. Representative mineral compositions are presented in Supplementary Tables 1, 2, 3, 4 and 5.

Laser-ablation-ICP-MS. Trace element abundances in garnet and clinopyroxene were analysed in situ with a single collector sector field ICP-MS system (Element 2, ThermoFisher Scientific) combined with a Resolution M-50 (Resonatics) $193 \mathrm{~nm}$ ArF excimer laser (ComPexPro 102F, Coherent) system at the Frankfurt Isotope and Element Research Center (FIERCE) Goethe Universität Frankfurt am Main. Ablation was done in a 0.45 l/ min He stream and with an Ar sample gas flow rate of $0.85 \mathrm{l} / \mathrm{min}$. RF Power was set to $1350 \mathrm{~W}$ resulting in an oxide production rate of $0.5-0.6 \%$. Spotsizes of $26 \mu \mathrm{m}$ and $40 \mu \mathrm{m}$ were employed for clinopyroxene and garnet, respectively. The pulse frequency of the laser was set to $15 \mathrm{~Hz}$ and a laser energy of $100 \mathrm{~mJ}$ at $50 \%$ attenuation was applied, resulting in a laser fluence of $6-7 \mathrm{~J} / \mathrm{cm}^{2}$. Measurements were performed in low-resolution mode with $60 \mathrm{~s}$ acquisition times ( $20 \mathrm{~s}$ for background and $40 \mathrm{~s}$ for the measurement). NIST 612 glass was used for external calibration, with BIR-1 (USGS) glass and an in-house garnet standard PN2b serving as secondary standards. As an internal standard we used the Si content measured by microprobe from the same area of the particular grains. Average element concentrations obtained for the standards and for selected elements are given in Supplementary Table 6 . The standard error obtained by comparison of measured and published average element concentrations for BIR-1 glass is around $\pm 10 \%$. Data reduction was carried out on-line with the GLITTER software ${ }^{50}$.

Determination of $\mathrm{Fe}^{3+} / \Sigma \mathrm{Fe}$ in garnet and spinel. Accurate measurement of $\mathrm{Fe}^{3+}$ concentrations in garnet or spinel is essential for estimating the oxidation state of the peridotites. Where adequate sample material was available, $\mathrm{Fe}^{3+} / \Sigma \mathrm{Fe}$ was determined by Mössbauer spectroscopy at the Goethe Universität Frankfurt am Main following the data collection and analysis procedures described in Woodland \& Koch $^{51}$ and Woodland et al. $^{40}$ for garnet and spinel, respectively. Optically clean separates were hand-picked under a binocular microscope. Spinels were treated sequentially with $\mathrm{HF}$ and $\mathrm{HCl}$ to eliminate any adhering silicates or magnetite alteration. Sample thickness was $\leq 5 \mathrm{mg} \mathrm{Fe} / \mathrm{cm}^{2}$ to avoid potential saturation effects. Spectra were obtained at room temperature with the spectrometer operating in constant acceleration mode with a velocity ramp of $\pm 5 \mathrm{~mm} / \mathrm{s}$.

For other garnet-bearing samples, the flank method was used to determine the $\mathrm{Fe}^{3+} / \Sigma \mathrm{Fe}$ of garnet with the microprobe following the procedures of Höfer et al. ${ }^{52}$ and Höfer and Brey ${ }^{53}$. Measurement conditions were $15 \mathrm{kV}$, $120 \mathrm{nA}$ and a beam diameter of $1 \mu \mathrm{m}$. Garnet from several samples was analysed by both Mössbauer spectroscopy and the flank method in order to verify consistency between to the two approaches. These yielded the following $\mathrm{Fe}^{3+} / \Sigma \mathrm{Fe}$ ratios: JPN3B Möss $=0.07$, flank $=0.08,0.08,0.08,0.10$; JPS6B Möss $=0.05$, flank $=0.05,0.03 ; \mathrm{X} 04$ Möss $=0.03$, flank $=0.03,0.04,0.02$, with multiple flank measurements determined on different grains. The $\mathrm{Fe}^{3+} /$ $\Sigma \mathrm{Fe}$ of spinel from many of the spinel peridotites was determined using the microprobe and employing a set of secondary standards following the measurement protocol of Wood and $\mathrm{Virgo}^{54}$. Uncertainties in $\mathrm{Fe}^{3+} / \Sigma \mathrm{Fe}$ are assessed as: \pm 0.01 for the determinations by Mössbauer spectroscopy, $\pm 0.01-0.02$ for garnets analysed by the flank method and \pm 0.025 for spinels analysed by microprobe using secondary standard $s^{55,56}$. Measured $\mathrm{Fe}^{3+} / \Sigma \mathrm{Fe}$ for garnet and spinel are provided in Supplementary Tables 4 and 5.

Thermobarometry. Equilibration temperatures for the spinel peridotites were calculated using the olivinespinel equilibrium as calibrated by Li et al. ${ }^{57}$. For one sample from Pelly Bay (TU18), the temperature was estimated from the clinopyroxene geothermometer of Nimis and Taylor ${ }^{58}$ due to the fact that both olivine and orthopyroxene had been destroyed by hydrothermal alteration. The corresponding equilibration pressure for the spinel peridotites was estimated by projecting the calculated temperatures onto the well-established geotherms for Somerset Island ${ }^{59}$ and Pelly Bay ${ }^{9}$. For the garnet-bearing peridotites of Somerset Island, temperatures and pressures were calculated iteratively using the olivine-garnet geothermometer of O'Neill and Wood ${ }^{60}$ in combination with the garnet-orthopyroxene geobarometer of Brey and Köhler ${ }^{61}$. Uncertainties in pressure are considered to be about $\pm 0.3 \mathrm{GPa}^{61}$. For the Pelly Bay suite, the alteration of olivine and orthopyroxene in samples TU15 and TU16 necessitated the application of the Ni-in-garnet geothermometer ${ }^{62}$. Considering the similarities in major and trace element composition of garnet between samples TU15 and TU14-b2 and between TU16 and TU13-a2-3 (see Supplementary Tables 4, 6), the orthopyroxene composition from the latter samples was applied to TU15 and TU16 in order to estimate a pressure of equilibration using the garnet-orthopyroxene geobarometer ${ }^{61}$. To maintain consistency within this sample suite, the temperature of all four garnet-bearing 
samples from Pelly Bay were computed on the basis of the Ni-in-garnet geothermometer ${ }^{62}$. The estimates of temperature and pressure of equilibration for all samples are listed in Supplementary Table 7.

Calculation of oxygen fugacity. Combining measured $\mathrm{Fe}^{3+} / \sum \mathrm{Fe}$ for garnet and spinel as described above with their respective total $\mathrm{Fe}$ contents determined from electron microprobe analysis, we can derive $\mathrm{Fe}^{3+}$ concentrations in these two phases. This information, along with the results of thermobarometry (Supplementary Table 7) enables calculation of the $f \mathrm{O}_{2}$ conditions experienced by each sample prior to entrainment using equilibria involving the Fe-bearing components of olivine, orthopyroxene and either garnet or spinel. The $f \mathrm{O}_{2}$ values, expressed as $\Delta \log f \mathrm{O}_{2}$ relative to the fayalite-magnetite-quartz reference oxygen buffer (FMQ) were computed from the oxybarometer calibrations of Stagno et al. ${ }^{30}$ for garnet-bearing and Wood et al. ${ }^{31}$ for spinel-bearing peridotites (see Supplementary Table 7). For five samples that contained garnet and spinel, we were able to estimate $\Delta \log f \mathrm{O}_{2}$ values based upon both equilibria (Supplementary Table 7). Uncertainties in the $f \mathrm{O}_{2}$ calculations are estimated to be \pm 0.6 and $\pm 0.5 \mathrm{log}$ units for the garnet and spinel-based calibrations, respectively. Since both olivine and orthopyroxene were strongly altered in samples TU15, TU16 and TU18, we estimated the $f \mathrm{O}_{2}$ using olivine-orthopyroxene pairs borrowed from other samples that had similar compositional characteristics. For TU18, we made calculations with the silicate compositions from K13A1, K13A4 and K15a4 since the cr\# of spinel in these three samples $(0.34,0.25,0.35$, respectively) effectively brackets that measured in TU18 (0.31). The difference in $\Delta \log f \mathrm{O}_{2}$ calculated from these three different olivine-orthopyroxene pairs was $\sim 0.1 \log$ units; much smaller than the overall uncertainty of the calibration. The silicates from TU13-a2-3 and TU14-b2 were respectively used for samples TU16 and TU 15, since these samples contain garnet with very similar compositions, including trace element signatures and derived Ni-in-garnet temperatures (see Supplementary Tables 4, 6 and 7$)$.

Received: 27 November 2020; Accepted: 1 February 2021

Published online: 11 February 2021

\section{References}

1. Jordan, T. H. The continental tectosphere. Rev. Geophys. 13, 1-12 (1975).

2. Jordan, T. H. Structure and formation of the continental tectosphere. J. Petrol. Spec. Lithosphere Issue 11-37. https://doi.org/10.1093/ petrology/Special_Volume.1.11 (1988).

3. James, D. E., Fouch, M. J., Van Decar, J. C., van der Lee, S. \& Kaapvaal Seismic Group. Tectospheric structure beneath southern Africa. Geophys. Res. Lett. 28, 2485-2488 (2001).

4. Griffin, W. L. et al. Lithosphere mapping beneath the North American plate. Lithos 77, 873-922 (2004).

5. Muller, M. R. et al. Lithospheric structure, evolution and diamond prospectivity of the Rehoboth Terrane and western Kaapvaal Craton, southern Africa: Constraints from broadband magnetotellurics. Lithos 112S, 93-105 (2009).

6. Snyder, D. B., Humphreys, E. \& Pearson, D. G. Construction and destruction of some North American cratons. Tectonophys. 694, 464-485 (2017).

7. Berman, R. G. et al. The Arrowsmith orogeny: geochronological and thermobarometric constraints on its extent and tectonic setting in the Rae craton, with implications for pre-Nuna supercontinent reconstruction. Precambrian Res. 232, 44-69 (2013).

8. Snyder, D. B., Berman, R. G., Kendall, J.-M. \& Sanborn-Barrie, M. Seismic anisotropy and mantle structure of the Rae craton, central Canada, from joint interpretation of SKS splitting and receiver functions. Precambrian Res. 232, 189-208. https://doi. org/10.1016/j.precamres.2012.03.003 (2013).

9. Liu, J. et al. Age and evolution of the deep continental root beneath the central Rae craton, northern Canada. Precambrian Res. 272, 168-184 (2016).

10. Hoffmann, P. F. The origin of Laurentia: Rae craton as the backstop for proto-Laurentian amalgamation by slab suction. Geosci. Canada 41, 313-320 (2014).

11. Berman, R. G., Davis, W. J. \& Pehrsson, S. Collisional Snowbird tectonic zone resurrected: growth of Laurentia during the 1.9 Ga accretionary phase of the Hudsonian orogeny. Geology 35, 911-914 (2007).

12. Martel, E., van Breemen, O., Berman, R. G. \& Pehrsson, S. Geochronology and tectonometamorphic history of the Snowbird Lake area, Northwest Territories, Canada: New insights into the architecture and significance of the Snowbirdtectonic zone. Precambrian Res. 161, 201-230 (2008).

13. Kjarsgaard, B.A. Kimberlite-hosted diamond. in Eckstrand, O.R., Sinclair, W.D., Thorpe, R.I. (eds.) Geology of Canadian Mineral Deposit Types, Vol. 8, 557-566. (Decade of North American Geology Geology of Canada, 1996).

14. Schmidberger, S. S. \& Francis, D. Nature of the mantle roots beneath the North American craton: Mantle xenolith evidence from Somerset Island Kimberlites. Lithos 48, 195-216 (1999).

15. Schmidberger, S. S. \& Francis, D. Constraints on the trace element composition of the Archean mantle root beneath Somerset Island, Arctic Canada. J. Petrol. 42, 1095-1117 (2001).

16. Schmidberger, S. S., Simonetti, A. \& Francis, D. Sr-Nd-Pb isotope systematics of mantle xenoliths from Somerset Island kimberlites: Evidence for lithosphere stratification beneath Arctic Canada. Geochim. Cosmochim. Acta 65, 4243-4255 (2001).

17. Schmidberger, S. S., Simonetti, A., Francis, D. \& Gariépy, C. Probing Archean lithosphere using the Lu-Hf isotope systematics of peridotite xenoliths from Somerset Island kimberlites, Canada. Earth Planet. Sci. Lett. 197, 245-259 (2002).

18. Irvine, G. J. et al. Re-Os isotope and PGE study of kimberlite-derived peridotite xenoliths from Somerset Island and a comparison to the Slave and Kaapvaal cratons. Lithos 71, 461-488 (2003).

19. Bragagni, A. et al. The geological record of base metal sulfides in the cratonic mantle: A microscale 187 Os/188Os study of peridotite xenoliths from Somerset Island, Rae Craton (Canada). Geochim. Cosmochim. Acta 216, 264-285 (2017).

20. Snyder, D. B., Craven, J. A., Pilkington, M. \& Hillier, M. J. The 3-dimensional construction of the Rae craton, central Canada. Geochem. Geophys. Geosyst. 16, 3555-3574 (2015).

21. Kjarsgaard, B. A., Heaman, L. M., Sarkar, C. \& Pearson, D. G. The North America mid-Cretaceous kimberlite corridor: An OIBtype deep mantle source triggered by Farallon subduction. Geochem. Geophys. Geosyst. https://doi.org/10.1002/2016GC006761 (2017).

22. Kienlen, B. et al. The Amaruk project in Canada's New Pelly Bay Diamond District. in 9th International Kimberlite Conference Extended Abstract No. 9IKC-A-00334 (2008). 
23. Kjarsgaard, B.A. \& Peterson, T.D. Kimberlite-derived ultramafic xenoliths from the diamond stability field: A new Cretaceous geotherm for Somerset Island, Northwest Territories. in Current Research, Part B, Geological Survey of Canada, Paper 92-1B, 1-6 (1992).

24. Harte, B. Rock nomenclature with particular relation to deformation and recrystallisation textures in olivine-bearing xenoliths. J. Geol. 85, 279-288 (1977).

25. Nicolas, A., Lucazeau, F. \& Bayer, R. Peridotite xenoliths in Massif Central basalts: textural and geophysical evidence for asthenospheric diapirism. In Mantle Xenoliths (ed. Nixon, P. H.) 563-574 (John Wiley, Chichester, 1987).

26. Grütter, H. S., Gurney, J. J., Menzies, A. H. \& Winter, F. An updated classification scheme for mantle-derived garnet, for use by diamond explorers. Lithos 77, 841-857 (2004).

27. McDonough, W. F. \& Sun, S. S. The composition of the Earth. Chem. Geol. 120, 223-253 (1995).

28. Griffin, W. L. \& Ryan, C. G. Trace-elements in indicator minerals-Area selection and target evaluation in diamond exploration. J. Geochem. Explor. 53, 311-337 (1995).

29. Hoal, K. E. O., Hoal, B. G., Erlank, A. J. \& Shimizu, N. Metasomatism of the mantle lithosphere recorded by rare earth elements in garnets. Earth Planet. Sci. Lett. 126, 303-313 (1994).

30. Stagno, V., Ojwang, D. O., McCammon, C. A. \& Frost, D. J. The oxidation state of the mantle and the extraction of carbon from Earth's interior. Nature 493(7430), 84-88. https://doi.org/10.1038/nature11679 (2013).

31. Wood, B. J., Bryndzia, L. T. \& Johnson, K. E. Mantle oxidation state and its relationship to tectonic environment and fluid speciation. Science 248(4953), 337-345 (1990).

32. Griffin, W. L., Shee, S. R., Ryan, C. G., Win, T. T. \& Wyatt, B. A. Harzburgite to lherzolite and back again: Metasomatic processes in ultramafic xenoliths from the Wesselton kimberlite, Kimberley, South Africa. Contrib. Mineral. Petrol. 134, 232-250 (1999).

33. Shu, Q. \& Brey, G. P. Ancient mantle metasomatism recorded in subcalcic garnet xenocrysts: Temporal links between mantle metasomatism, diamond growth and crustal tectonomagmatism. Earth Planet. Sci. Lett. 418, 27-39 (2015).

34. Grégoire, M., Bell, D. \& Le Roex, A. P. Garnet lherzolites from the Kaapvaal Craton (South Africa): Trace element evidence for a metasomatic history. J. Petrol. 44, 629-657 (2003).

35. Coltorti, M., Bonadiman, C., Hinton, R. W., Siena, F. \& Upton, B. G. J. Carbonatite metasomatism of the oceanic upper mantle: Evidence from clinopyroxenes and glasses in ultramafic xenoliths of Grande Comore, Indian Ocean. J. Petrol. 40, 133-165 (1999).

36. Uenver-Thiele, L., Woodland, A. B., Seitz, H.-M., Downes, H. \& Altherr, R. Metasomatic processes revealed by trace element and redox signatures of the lithospheric mantle beneath the Massif Central, France. J. Petrol. 58, 395-422 (2017).

37. Zack, T., Foley, S. F. \& Jenner, G. A. A consistent partition coefficient set for clinopyroxene, amphibole and garnet from laser ablation microprobe analysis of garnet pyroxenites from Kakanui, New Zealand. Neues Jahrb. Mineral. Abhand. 172, 23-41 (1997).

38. Luth, R. W. \& Stachel, T. The buffering capacity of lithospheric mantle: Implications for diamond formation. Contrib. Mineral. Petrol. 168, 1083 (2014).

39. Frost, D. J. \& McCammon, C. A. The redox state of Earth's mantle. Ann. Rev. Earth Planet. Sci. 36, 389-420 (2008).

40. Woodland, A. B., Kornprobst, J. \& Tabit, A. Ferric iron in orogenic lherzolite massifs and controls of oxygen fugacity in the upper mantle. Lithos 89, 222-241 (2006).

41. Yaxley, G. M., Berry, A. J., Rosenthal, A., Woodland, A. B. \& Paterson, D. Redox preconditioning deep cratonic lithosphere for kimberlite genesis-Evidence from the central Slave Craton. Sci. Rep. 7, 30 (2017).

42. Creighton, S., Stachel, T., Eichenberg, D. \& Luth, R. W. Oxidation state of the lithospheric mantle beneath Diavik diamond mine, central Slave craton, NWT, Canada. Contrib. Mineral. Petrol. 159, 645-657 (2009).

43. Kennedy, C. S. \& Kennedy, G. C. The equilibrium boundary between graphite and diamond. J. Geophys. Res. 81, 2467-2470 (1976).

44. Yaxley, G. M., Berry, A. J., Kamenetsky, V. S., Woodland, A. B. \& Golovin, A. V. An oxygen fugacity profile through the Siberian Craton-Fe K-edge XANES determinations of $\mathrm{Fe}^{3+} / \Sigma \mathrm{Fe}$ in garnets in peridotite xenoliths from the Udachnaya East kimberlite. Lithos 140-141, 142-151. https://doi.org/10.1016/j.lithos.2012.01.016 (2012).

45. Creighton, S. et al. Oxidation of the Kaapvaal lithospheric mantle driven by metasomatism. Contrib. Mineral. Petrol. 157, 491-504 (2009).

46. Canil, D. \& Wei, K. Constraints on the origin of mantle-derived low Ca garnets. Contrib. Mineral. Petrol. 109, 421-430 (1992).

47. Stachel, T., Viljoen, K. S., Brey, G. \& Harris, J. W. Metasomatic processes in lherzolitic and harzburgitic domains of diamondiferous lithospheric mantle: REE in garnets from xenoliths and inclusions in diamonds. Earth Planet. Sci. Lett. 159, 1-12 (1998).

48. Wang, H., van Hunen, J. \& Pearson, D. G. Making Archean cratonic roots by lateral compression: A two-stage thickening and stabilization model. Tectonophys. 746, 562-571 (2018).

49. Foley, S. F. A reappraisal of redox melting in the Earth's mantle as a function of tectonic setting and time. J. Petrol. 52, 1363-1391 (2011).

50. Van Achterbergh, E., Ryan, C. G., Jackson, S. E. \& Griffin, W. L. Data reduction software for LA-ICP-MS: appendix. In: Sylvester, P. J. (ed.) Laser Ablation-ICP-Mass Spectrometry in the Earth Sciences: Principles and Applications. Mineral. Assoc. Canada, Short Course Series 29, 239-243 (2001).

51. Woodland, A. B. \& Koch, M. Variation in oxygen fugacity with depth in the upper mantle beneath the Kaapvaal craton, Southern Africa. Earth Planet. Sci. Lett. 214, 295-310 (2003).

52. Hofer, H. E., Brey, G. P., Schulz-Dobrick, B. \& Oberhaensli, R. The determination of the oxidation state of iron by the electron microprobe. Eur. J. Mineral. 6, 407-418 (1994).

53. Höfer, H. E. \& Brey, G. P. The iron oxidation state of garnet by electron microprobe: Its determination with the flank method combined with major-element analysis. Am. Mineral. 92, 873-885 (2007).

54. Wood, B. J. \& Virgo, D. Upper mantle oxidation state: ferric iron contents of lherzolite spinels by ${ }^{57}$ Fe Mössbauer spectroscopy and resultant oxygen fugacities. Geochim. Cosmochim. Acta 53, 1277-1291 (1989).

55. Woodland, A. B., Kornprobst, J. \& Wood, B. J. Oxygen thermobarometry of orogenic lherzolite massifs. J. Petrol. 33, 203-230 (1992).

56. Woodland, A. B., Kornprobst, J., Mc Pherson, E., Bodinier, J.-L. \& Menzies, M. A. Metasomatic interactions in the lithospheric mantle: Petrologic evidence from the Lherz Massif, French Pyrenees. Chem. Geol. 134, 83-112 (1996).

57. Li, J., Kornprobst, J., Vielzeuf, D. \& Fabriès, J. An improved experimental calibration of the olivine-spinel geothermometer. Chin. J. Geochem. 14, 68-77. https://doi.org/10.1007/BF02840385 (1995).

58. Nimis, P. \& Taylor, W. R. Single clinopyroxene thermobarometry for garnet peridotites. Part I. Calibration and testing of a Cr-inCpx barometer and an enstatite-in-Cpx thermometer. Contr. Mineral. Petrol. 139, 541-554 (2000).

59. Mather, K. A., Pearson, D. G., McKenzie, D., Kjarsgaard, B. A. \& Priestley, K. Constraints on the depth and thermal history of cratonic lithosphere from peridotite xenoliths, xenocrysts and seismology. Lithos 125, 729-742 (2011).

60. O'Neill, H. S. C. \& Wood, B. J. An experimental study of Fe-Mg partitioning between garnet and olivine and its calibration as a geothermometer. Contrib. Mineral. Petrol. 70, 59-70. https://doi.org/10.1007/BF00371872 (1979).

61. Brey, G. P. \& Köhler, T. Geothermobarometry in four-phase lherzolites II. New thermobarometers, and practical assessment of existing thermobarometers. J. Petrol. 31, 1353-1378. https://doi.org/10.1093/petrology/31.6.1353 (1990).

62. Canil, D. The Ni-in-garnet geothermometer: Calibration at natural abundances. Contrib. Mineral. Petrol. 136, 240-246 (1999). 


\section{Acknowledgements}

This work was primarily supported by a grant from the Deutsche Forschungsgemeinschaft to ABW (Wo652/291). FIERCE is financially supported by the Wilhelm and Else Heraeus Foundation and by the Deutsche Forschungsgemeinschaft (DFG, INST 161/921-1 FUGG and INST 161/923-1 FUGG), which is gratefully acknowledged. Laura Uenver-Thiele helped with acquiring some of the microprobe measurements. The manuscript was improved through reviews by Arno Rohrbach and two anonymous reviewers. This is FIERCE contribution No. 56.

\section{Author contributions}

D.G.P. and B.A.K. collected the sample materials and performed preliminary sample characterisation. C.G., A.B.W. and T.S. did the microprobe analyses. C.G. and H.E.H. performed the flank measurements to obtain $\mathrm{Fe}^{3+} / \Sigma \mathrm{Fe}$ on some garnets. T.S. and A.B.W. obtained and evaluated the Mössbauer spectra to determine $\mathrm{Fe}^{3+} / \Sigma \mathrm{Fe}$ of some garnet and spinel. C.G., T.S. and H.-M.S. performed the laser ablation LA-ICP-MS measurements. C.G., A.B.W., T.S., H.E.H. and H.-M.S. interpreted the chemical data. A.B.W. wrote the manuscript with input from all other co-authors.

\section{Funding}

Open Access funding enabled and organized by Projekt DEAL.

\section{Competing interests}

The authors declare no competing interests.

\section{Additional information}

Supplementary Information The online version contains supplementary material available at https://doi. org/10.1038/s41598-021-83261-6.

Correspondence and requests for materials should be addressed to A.B.W.

Reprints and permissions information is available at www.nature.com/reprints.

Publisher's note Springer Nature remains neutral with regard to jurisdictional claims in published maps and institutional affiliations.

(c) (i) Open Access This article is licensed under a Creative Commons Attribution 4.0 International License, which permits use, sharing, adaptation, distribution and reproduction in any medium or format, as long as you give appropriate credit to the original author(s) and the source, provide a link to the Creative Commons licence, and indicate if changes were made. The images or other third party material in this article are included in the article's Creative Commons licence, unless indicated otherwise in a credit line to the material. If material is not included in the article's Creative Commons licence and your intended use is not permitted by statutory regulation or exceeds the permitted use, you will need to obtain permission directly from the copyright holder. To view a copy of this licence, visit http://creativecommons.org/licenses/by/4.0/.

(C) The Author(s) 2021 